\title{
Health Status of Healthcare Professionals Working in an Institute for Chronically Ill Psychiatric Patients
}

Authors' contribution:

A) conception and design of the study

B) acquisition of data

C) analysis and interpretation of data

D) manuscript preparation

E) obtaining funding
Katalin Nagyváradi $^{1 \mathrm{~A}-\mathrm{E}}$, Zsuzsa Mátrai ${ }^{2 \mathrm{~A}-\mathrm{E}}$

University of West Hungary, Hungary
ABSTRACT

Several research works in the related international literature on sociology and health sciences deal with the state of health in one selected population. In these studies, the chosen sample is often connected with special jobs, especially with healthcare professionals and their working conditions. These studies predominantly examine the self-rated subjective health status using questionnaires. There are others that assess the state of health based not only on self-rated subjective indicators, but also using objective data gained by measuring. Considering the international experiences, we chose a special population in our research - healthcare professionals working in an institute for chronically ill psychiatric patients. Our choice was influenced by the fact that we wanted to include their unique working conditions when exploring and assessing their health status. Moreover, our approach was to assess the objective state of health alongside the subjective factors, as our hypothesis was that the majority of the indicators presumably coincided. The data were collected with the help of three questionnaires and some indicators of the objective health statuses were measured. The findings were processed using the SPSS 17.0 mathematical-statistical software package. Following the descriptive statistics, we applied hierarchic cluster-analysis based on results of the WHOQOLD-BREF26 life-quality questionnaire, the WHO WBI-5 Well Being Index, and on the body composition analysis. The results show the objective and subjective health status of population and the factors that influenced it; the working conditions and the interpersonal contacts in the workplace. The conclusion was that in the examined population the subjective and objective health status doesn't coincide.

self-rated health. obiective health status. cluster changers

KEYWORDS

\section{Introduction}

A great number of research studies in the related international literature on sociology and health sciences deal with the state of health in one selected population. In these research studies the chosen sample is connected with special jobs, often with healthcare professionals and their working conditions. Their starting point is that healthcare professionals' jobs differ very much from other occupations' as they have a heavy workload under huge physical and psychological working conditions (Gray-Toft \& Anderson, 1981; 
Dewe, 1987; Borrill et al., 1998; Hegedűs \& Riskó, 2006; Weyers et al., 2006). In many studies, the selfrated subjective health status and the impact of some macro factors on it are examined using questionnaires (Réthelyi, 2006; Csoboth, 2006; Kovács \& Jeszenszky, 2006; Gémes, 2006; Szumska, 2006; Túry et al., 2013; Boros et al., 2013; Kopp et al., 2006). The strongest relationship was found between the people's poor state of health and their disadvantaged socioeconomic situation, the lack of their social support and the low level of their employment (Karasek \& Theorell, 1990; Marmot et al., 1998; Molarius et al., 2006). It was discovered that the high expectations towards the job, together with low supervision over the work done, hinder a more realistic self-assessment of health (Karasek \& Theorell, 1990). The research studies differ from each other methodically. Beside the above-mentioned self-rated subjective indicators, they also use objective data based on measurements (Idler et al., 2004; Benyamins et al., 2004; Józan, 2013; Wu et al., 2013; van der Linde et al., 2013; Mavaddat et al., 2014).

\section{Objectives and hypothesis}

This article is based on our research, the major objective of which was to examine the health status of healthcare professionals working in an institute for chronically ill psychiatric patients. Our choice was influenced by the fact that we also wanted to discover how their unique working conditions influence the state of their health. In light of that, our research is limited to the employees of a certain institute, so it can also be considered as a special case study.

Moreover, our aim was to compare healthcare professionals' objective health statuses with their selfrated state of health. Our hypothesis was that there is a correlation between the indicators of objective heath status and the self-reported health. In other words: it is assumed that most research subjects rate their health status similar to what the objective measurements indicate.

\section{Methods}

\section{Population}

The research was conducted during summer 2012 in West Hungary at a psychiatric institute. At that time in the institute, 338 employees were working with the patients; they were regarded as the total population. Out of them, 131 people accepted to participate in the investigation, almost $40 \%$ of the total population $(38.7 \%)$.

The examined population can be characterized as follows:

Like in the total population, one-third of the research subjects have been in this line of work for more than 20 years, and 50\% of them for at least 6 years. Although they had been working in the same institute, their actual working place was not the same, because within the institute they were transferred from one department to another every one or two years. Their decision to choose this particular workplace was influenced by several factors. Some of them wanted to be employed in this institute because they were promised to have an interesting job, some were committed emotionally to the profession, and a few believed in the usefulness of the work.

Similar to the total population, the examined population consisted mostly of women, $70 \%$ of them were employed as nurses, while the other $30 \%$ worked mostly as medical doctors and mental health nurses. Considering their age, more than two-thirds of them were between ages 30 and 60, only $0.8 \%$ were older than 60 , and $4.6 \%$ were younger than 30 . The level of their education was different: One-third of them got school-leaving examination, slightly less than one-third also attended vocational school, and only one-fifth of the research subjects earned a higher education degree (either higher professional qualification as a nurse, or college or university degree).

Regarding the examined population's personal life conditions, more than three-quarters of them lived in a family (in marriage or in a permanent relationship), and the majority of them had two or one children. 
Half of them live in the same town where the institute is, the other half live in a village on the outskirts of the town. The average duration of traveling to their workplace was less than 30 minutes.

\section{Measurement}

In order to assess the subjective state of health, each research subject had to fill out three functionally different questionnaires. The first one examined mental well-being based on the answers given to the five questions of the WHO WBI-5 international test. Using a five-point scale they had to indicate the frequency of the following feelings experienced in the previous two weeks: happiness and joy, calmness and relaxation, activity and vitality, activeness and restfulness on waking; they were also asked to share if anything peculiar happened.

The second questionnaire was also an international one, namely the WHOQOL-BREF26, which contained two general and 24 factual questions. The first of the two groups of questions asked information about the interviewees' satisfactions with their quality of life and about their self-rated health status. The factual questions intended to explore physical, mental, social and environmental dimensions by means of a five-point scale. Since this questionnaire had been widely used internationally, only a few examples are mentioned here to demonstrate the content of the individual dimensions. For instance, the questions concerning physical health included the research subjects' satisfaction with their ability to work and the extent to which physical pain interfered with their everyday activities. Regarding the psychological aspect, the questions attempted to reveal to what extent the research subjects enjoyed their life and how purposeful their life was according to their opinion. With respect to social interactions, the participants of the research were asked whether they received support from others when needed and to which degree they were content with their own interpersonal relationships. Concerning the environmental dimension, the individuals had to evaluate how satisfied they were with their accessibility to healthcare services and with the transportation.

Besides the above-mentioned international tests, a self-made questionnaire containing 56 questions was also used, asking about the place of employment, working conditions, professional development, health status and leisure. The research subjects were asked why they had chosen this particular place of employment, what their relationship was like with their bosses and with the patients, and what their opinion was about their financial, professional and moral recognition. They were also asked if they could have had career development discussion with their supervisor or with the human recourses manager if they wanted to. There were questions about basic health behavioral habits (e.g., alcohol consumption, smoking, physical activity), the amount of time spent on sick leave, and about major cultural and sporting activity in their free time, if they had any.

Regarding the indicators of objective health status ${ }^{1}$, we measured the ratio of height and body components (water, protein, mineral matter and fat), also the fat-muscle ratio, waist-hip ratio, the extent of abdominal obesity and the BMI (Body Mass Index) which is defined as the individual's body mass divided by the square of their height in meters.

\section{Data processing}

The data was processed using the SPSS 17.0 mathematical-statistical software package. The answers gathered by the questionnaire on individual living-conditions were analyzed with the help of descriptive statistics (frequency, relative frequency). Following the descriptive statistics, we applied hierarchic cluster analysis based on results of the WHOQOLD-BREF26 life-quality questionnaire, the WHO WBI-5 WellBeing Index, and on the body composition analysis. The individual groups were set up using the Ward process. Based on the comparative patterns, the interviewees were classified into three groups. The clusters and the questions of the questionnaires were compared using crosstab analysis to identify which clusters were stronger or more sensitive in terms of the examined indicator. 


\section{Results}

\section{Subjective health status}

The descriptive statistical results regarding both the mental and physical health status were based upon the information collected by the aforementioned two international questionnaires. The findings of the research show that although two-thirds of the examined population evaluated the quality of their life positively, only one-third of them were satisfied with their state of health. A little more than half of them rated their physical health good or very good. These results are in harmony with the research data that shed light on the fact that more than half of the interviewees had enough energy for everyday life.

According to research data, the members of the examined population assessed their mental condition well. As far as enjoyment, $80 \%$ of them knew their purpose in life and more than half of them enjoyed life very much. Two-thirds of the examined population was happy and cheerful for half of the time; they were active and lively and were able to concentrate for long periods. Moreover, almost $50 \%$ of them said that they found peculiarities in their everyday lives. At the same time, more than half of the research subjects stated that they were not active and relaxed, and they did not feel very secure. Of the latter, $10 \%$ did not feel safe at all. The fact that approximately one-third of the examined population reported that they often felt sadness, hopelessness, or depression is also a negative indicator of their mental state. The considerable difference between quality of life and self-rated health might be explained by the lack of harmony between the physical and mental states of the interviewees. According to the data, the sense of insecurity has a negative effect on mental well-being.

\section{Objective health status}

The measurement of the body mass index (BMI) clearly indicated which category the individuals belonged to. The results showed that $44 \%$ of the participants fell under the "normal" domain, $56 \%$ of them had excess weight to a varying extent. Overweight individuals were categorized as follows: $30.8 \%$ were "overweight", $20 \%$ were "slightly overweight", $4.6 \%$ were "moderately overweight", while $0.8 \%$ suffered from "serious obesity".

The indicators of body composition were based on the measurement of the muscle mass, fat mass, distribution of fat in the body, fat-muscle ratio in the limbs and on the main body components. The research data show that $68.5 \%$ of the examined people had a normal percentage of muscle mass, $20.8 \%$ had more muscle mass than normal, and $10.8 \%$ had less than the normal percentage. In terms of fat mass, the results show a much more unfavorable situation: only $40 \%$ of the interviewees had a healthy fat mass level, and the fat mass was above the healthy level with $56.9 \%$ of them. Relying upon these findings, we examined the amount of abdominal fat and the closely-related waist-hip ratio. All together, only $45.3 \%$ of the examined population had healthy abdominal fat values; for 54.5\%, abdominal fat was excessive for their age. Accordingly, the waist-hip ratio was high, being calculated at $81.7 \%$ for the women and $50 \%$ for the men.

The muscle-fat ratio was further examined in the upper and lower limbs, and in the trunk. Regarding the upper limbs, the muscle-fat ratio was not good, with almost two-thirds of the examined people; it exceeded the normal values (left arm: $61.5 \%$, right arm: 67.7\%). With respect to the trunk and the legs, almost all data showed normal values (trunk: 90.8\%, left leg: 96.2\%, right leg: 94.6\%).

Body composition is determined by the amount of water, protein and minerals in the body of the individual. According to the research findings with about two-thirds of the subjects all 3 components were at a healthy level (protein: 69.2\%, water: 69.2\%, minerals: 67.7\%); with the rest of them, the values fell mostly above and to a small extent under the healthy level (protein: $20.8 \%$, water: $23.1 \%$, minerals: $31.5 \%$ ).

Based on the results given by the body composition analyzer device, the calculated fitness score places $63.1 \%$ of the participants into the healthy ( 70 to 90 ) category while placing $36.9 \%$ of them into the category of poor health (under 70). All these data are in relationship to the indicators of abnormal body composition, 
in this particular case with high body weight and its unfavorable localization throughout the body - this is characteristic of more than half of the examined individuals.

Cross-examining the health status, the research subjects had to report why, how often, and for how long they claimed sick pay in the previous last 12 months. A little more than half of the respondents said they had not been on the sick list at all. The remaining interviewees (a little less than half) had been on sick leave partly because they had been sick (e.g., locomotor disease), and partly because one of their family members had been ill. On average, they were on the sick list two to three weeks; however, $10 \%$ of them did not work for more than a month.

\section{Factors influencing health status}

Data regarding the factors influencing the state of health of the examined population were collected by means of the questionnaire constructed by us. It comprised the research subjects' healthy behaviors, working conditions and social relationship.

Healthy behaviors

In reference to healthy behaviors, some factors that influence the state of health in the long run were examined, such as physical activity, alcohol consumption, smoking and participation in screening programs. Although the majority of the research subjects practiced sports only occasionally, they were physically active; they rode a bicycle, many of them went to work cycling, and worked physically in their garden.

Their custom in connection with the consumption of alcohol could not be clarified, since more than half of the individuals chose to ignore the question aimed at discovering it. Smoking seems not to be their bad habit at the time of the data collection as the majority of the respondents stated that they never smoked or if they did, they already gave it up, as an average five or less years ago.

The fact that they were employed in a public health institute is reflected in their participation rate in screening tests. The overwhelming majority of the interviewees had their blood pressure regularly measured, and approximately $75 \%$ of them had their blood sugar level checked annually. One-third of them had dental and ophthalmological screenings every 1 to 3 years. Slightly less than half of the women had a cervical scan every year, and one-third of them had mammograms as well.

\section{Working conditions}

Almost two-thirds of research subjects were very satisfied with their ability to work and their capacity for work, and the rest was satisfied at about average. However, their opinion about how tiring their work is differed considerably. One-third of them were of the opinion that their work is very hard, another one-third found that it varies, and the rest of them thought that it is not a problem to perform it. These viewpoints were more or less in harmony with their statement about how tired they felt after a shift. One-third of them felt tired mentally, while more than half of the individuals were exhausted both mentally and physically. It is also essential to note that only half of the employees felt appreciation and recognition for the job they did. These people did report some professional appreciation received, however, only less than $10 \%$ of them were happy with their financial recognition. In terms of professional development, there was a huge claim and opportunity to take part in further education in connection with their job. However their professional growth was hindered by the fact that although the individuals could express their opinions, they were often disregarded.

\section{Social relationships}

The interviewees' relationship with their colleagues was partly in connection with their working conditions. Two-thirds of them had more of a comrade-type relationship with their fellow workers than a friendship, and the majority of them rated their working relationships as good. Generally speaking, the research subjects were satisfied with their interpersonal relationships, both with their family members and 
with their friends. They spent their free time with them, having get-togethers with family and friends, and participating in sporting and cultural activities.

\section{Relationship between the subjective and objective indicators}

In order to discover the relationship between the subjective and objective health of the employees working in a special health institute, we chose a mathematical statistical method, namely cluster analysis. The reported data about subjective health collected by the international questionnaires and the measured data about objective health were grouped into three subjective clusters and three objective clusters. Within the two groups, the first cluster contained the people with the best results, the second one comprised the individuals with average data, and the third cluster classified the individuals with the poorest results. The clusters were named accordingly.

Table 1. Name of clusters

\begin{tabular}{|l|l|}
\hline Subjective clusters & Objective clusters \\
\hline 1. Fine and satisfied (67 individuals) & A. Healthy (60 individuals) \\
\hline 2. Fine and unsatisfied (17 individuals) & B. Health-protecting (37 individuals) \\
\hline 3. Unwell and unsatisfied (43 individuals) & C. Health-destroying (32 individuals) \\
\hline
\end{tabular}

The Figure 1, 2, and 3 show the individuals who changed their cluster ("cluster-migrants") after their subjective and objective health indicators were compared. The numbers in the arrows identify these people.

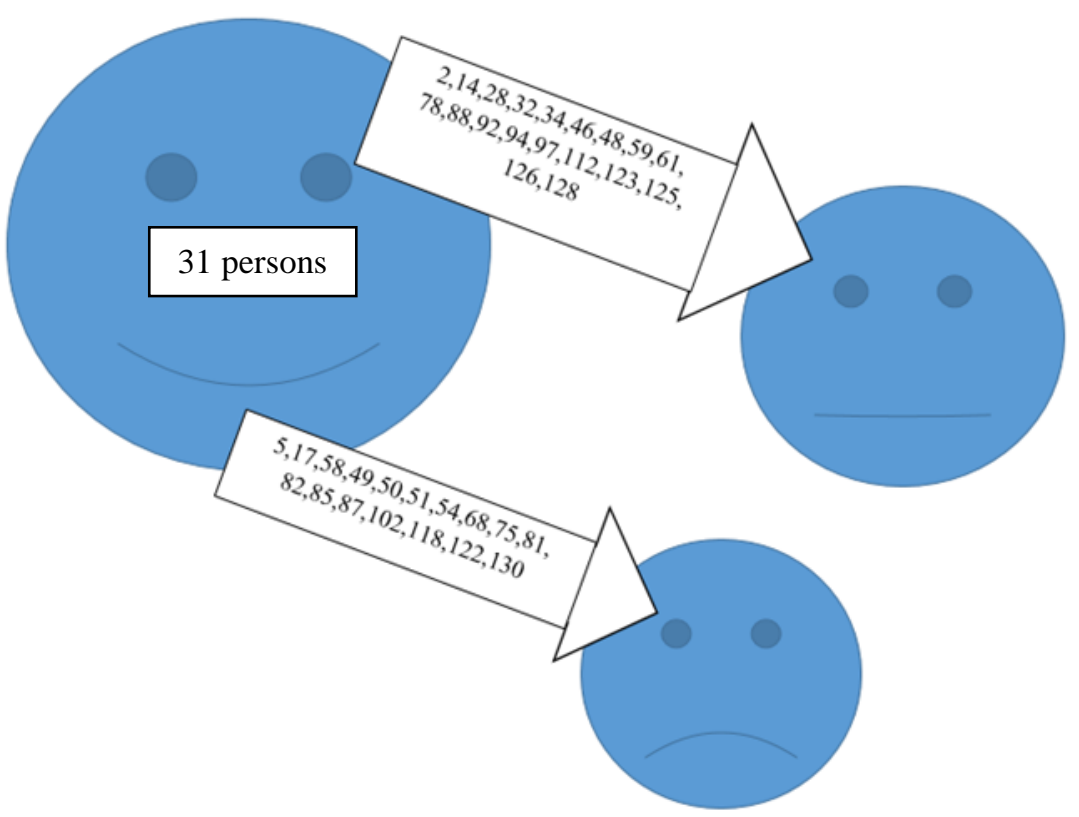

Figure 1. Cluster changers from the Fine and satisfied cluster 


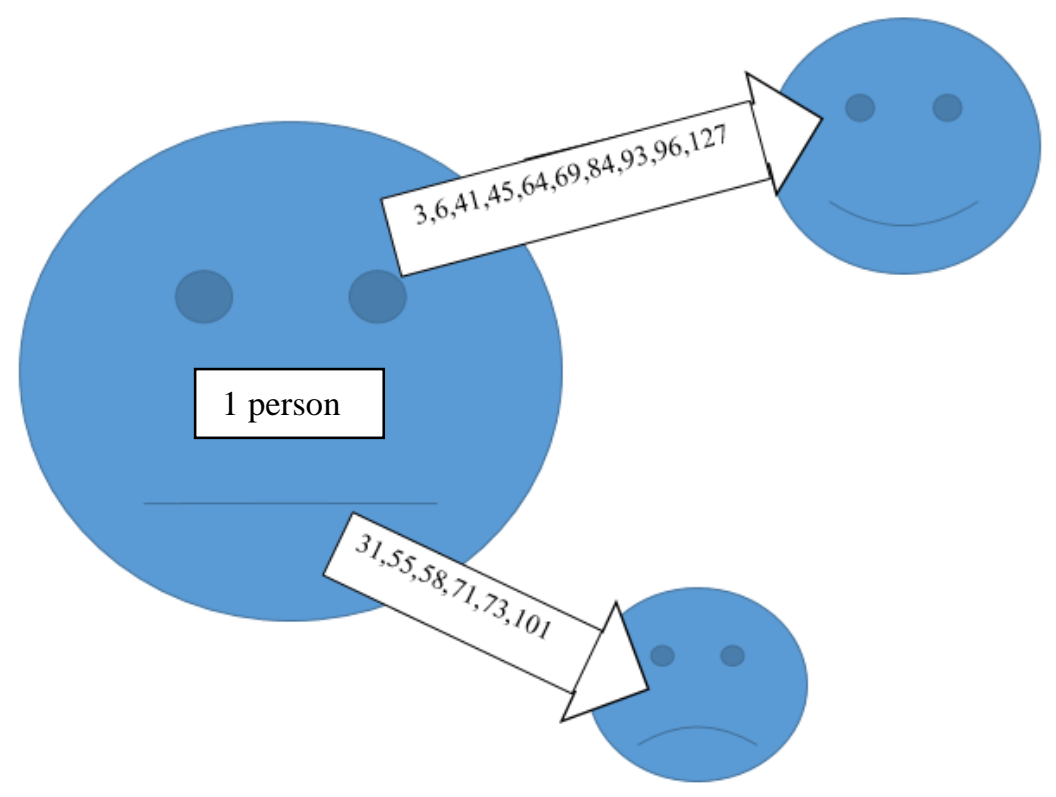

Figure 2. Cluster changers from the Fine and unsatisfied cluster

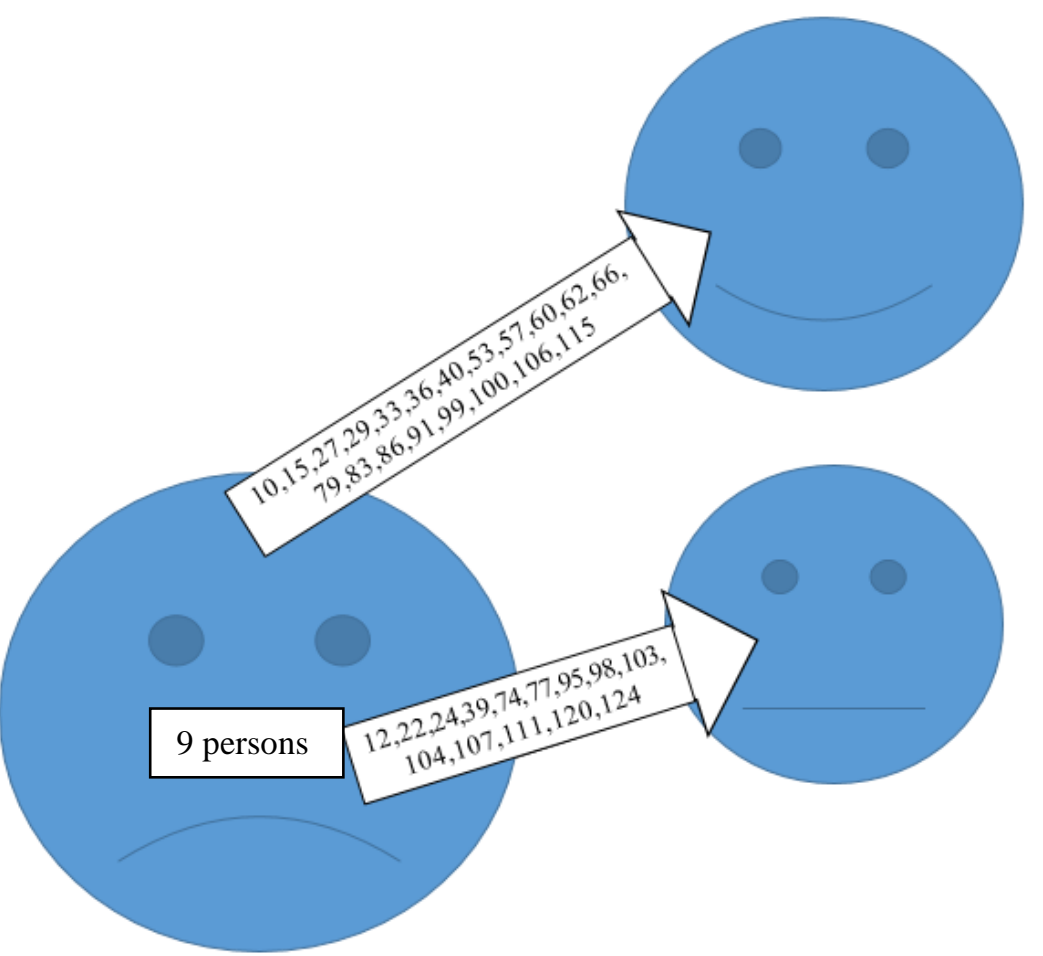

Figure 3. Cluster changers from the Unwell and unsatisfied cluster

On all three figures, the heads on the left side indicate the interviewees belonging to the original subjective clusters. The expressions of the faces represent their health status based on their self-rating. The arrows pointing outwards from these initial clusters show the serial number of the individuals whose objective indicators differed from how they assessed their own health. Figure 1 demonstrates the number of people (31) with coinciding subjective and objective health indicators; 19 individuals got into the second 
objective category (health-protecting); while 17 people got into the lowest objective category (healthdestroying).

Figure 2 shows a quite interesting phenomenon. Here it can be seen that only 1 person could reasonably assess their state of health, the greater part of the rest were healthier than they rated, and a slightly less proportion were in poorer conditions than they thought. Looking at the name of the second subjective cluster, it is apparent that based on their evaluation, the research subjects were fine in terms of health, but they were still unsatisfied. All these indicated the striking differences between the subjective and objective health indicators.

Figure 3 shows an inverse migration compared to the first one. In this case, it is the objective indicators that are much better than the self-rated subjective ones. All together, 34 out of 43 individuals were healthy, or healthier than they thought.

\section{Conclusions}

In conclusion it can be stated that with the examined population consisting of healthcare professionals working in an institute for chronically ill psychiatric patients, the subjective health rating did not coincide with the objectively measured health indicators. The hypothesis of our research, according to which it was supposed that most research subjects rate their health status similar to their objective health indicated by objective measurements, was not verified.

Although the size of the population does not allow for a generalization of the results, it can be rightly declared that research studies on health status that rely merely on subjective, self-rated data do not provide a realistic picture about the state of health of any examined population. It is very important to emphasize this statement, because the analysis of both international and the national literature reveal that a great part of research studies on health status are based exclusively on self-rating. The outcome of our research - coined "cluster-migration" - raises the question: To which factors can it be attributed that many individuals underor over-rate their health status compared to their objective health indicators.

In order to give a grounded answer to the above-mentioned question, we propose a new approach for further investigations. In our research, there were several questions that intended to discover various dimensions of the research subjects' private sphere (e.g., working conditions, workload, amount of free time, family life), which might have an impact on both the subjective and objective states of health. Based on the experiences of our research, the quality of the private sphere, including relationships in the family, could have somatic and psychosomatic consequences. It would be hard to make a distinction between the somatic and psychosomatic phenomena based merely on subjective indicators. Instead of it, it could be beneficial to examine whether similar "cluster-migration" could be found, if the quality of private relationships were correlated with some objective health indicators. We make the attempt to answer this question with the help of a next research.

\section{REFERENCES}

Benjamins, M.R., Hummer R.A., Eberstein, I.W., Nam, C.B. (2004). Self-reported health and adult mortality risk: an analysis of cause-specific mortality. Social Science \& Medicne, 59: 1297-1306.

Boros, P., Finn, K.J., Ihász, F. (2013). Comparison of Wrist-worn to Waist-worn Actigraph physical activity data in Hungarian Adults. 60th ACSM Annual Meeting and 4th World Congress on Exercise is Medicine. Indianapolis, USA. Abstractbook. 125.

Borrill, C.S, Wall, T.D, West, M., Hardy, G.E., Shapiro, D.A, Haynes, C.E. (1998). Stress Among Staff in NHS Trusts: Final Report. Institute of Work Psychology, University of Sheffield, Sheffield, UK.

Csoboth, C. (2006). A magyar nők életminősége /Lifestyle of Hungarian woman/. In M. Kopp, M.E. Kovács (Eds.), A magyar népesség életminösége az ezredfordulón/The quality of life in the Hungarian population in the millennium/ (pp. 106-115). Budapest: Semmelweis Kiadó. 
Dewe, P.J. (1987). Identifying the causes of nurses' stress: a survey of New Zealand nurses. Work Stress , 1: 15-24.

Gémes, K. (2006). Sport és életminőség /Sport and quality of life/. In M. Kopp, M.E. Kovács (Eds.), A magyar népesség életminösége az ezredfordulón /The quality of life in the Hungarian population in the millennium/ (pp. 167180). Budapest: Semmelweis Kiadó.

Gray-Toft, P., Anderson, J.G. (1981). Stress among hospital nursing staff: its causes and effects. Social Science \& Medicine, 15A: 639-47.

Hegedűs, K., Riskó, Á. (2006). Súlyos betegekkel foglalkozó egészségügyi dolgozók testi-és lelkiállapota /Physical and mental health status of the patients with serious workers/. In M. Kopp, M.E. Kovács (Eds.), A magyar népesség életminösége az ezredfordulón /The quality of life in the Hungarian population in the millennium/ (pp. 302-313). Budapest: Semmelweis Kiadó.

Idler, E., Leventhal, H., Mc Laughlin, J., Leventhal, E. (2004). In sickness but not in health: self-ratings, identity, and mortality. Journal of Health and Social Behavior, 45: 336-356.

Józan, P. (2013). Az elhízás epidemiológiájának néhány hazai és nemzetközi vonatkozása /Some Hungarian and international aspect of obesity epidemiology/. Magyar Tudomány, 174/2013/7: 772-785.

Karasek, R., Theorell, T. (1990). Healthy work, stress productivity and the reconstruction of working life. New York: Basic Books.

Kopp, M., Skrabski Á., Székely, Á. (2006). Az életminőség nemi, életkor szerinti és területi jellemzői a magyar népesség körében a Hungarostudy 2002 vizsgálat alapján /The quality of life of sex, age and geographical features of the Hungarian population according to the 2002 Hungarostudy/. In M. Kopp, M.E. Kovács (Eds.), A magyar népesség életminősége az ezredfordulón /The quality of life in the Hungarian population in the millennium/. Semmelweis Kiadó, Budapest, 84-105.

Kovács, M.E., Jeszenszky, Z. (2006). Időskor és életminőség /Elderly and quality of life/. In M.,Kopp, M.E., Kovács (2006). A magyar népesség életminösége az ezredfordulón /The quality of life in the Hungarian population in the millennium/ (pp. 134-143). Budapest: Semmelweis Kiadó.

Marmot, M.G, Fuhrer, R., Ettner, S.L. (1998). Contribution of psychosocial factors to socioeconomic differences in health. Mibank $Q$, 76: 403-48.

Mavaddat, N., Parker, R.A., Sanderson ,S., Mant, J., Kinmonth, A.L. (2014). Relationship of self-rated health with Fatal and Non-Fatal Outcomes in Cardiovascular Disease: A Systematic Review and Meta-Analysis. www.plosone.org. letöltve: 2014.09.30

Molarius, A., Berglund,K., Erikkson, C., Lambe, M., Nordstörm, E., Erikkson, H.G., Feldman, I. (2006). Socioeconomic conditions, lifestyle factors, and self-rated health among men and women in Sweden. European Journal of Public Health, 17(2): 125-133.

Réthelyi, J. (2006). A középkorú magyar lakosság egészségi állapota és életminősége - A gazdasági aktivitás összefüggése az életminöség csökkenésével /Health status and quality of life of middle-aged Hungarian population The relationship between the economic activity and the decreases the quality of life/. In M.,Kopp, M.E., Kovács (2006). A magyar népesség életminösége az ezredfordulón /The quality of life in the Hungarian population in the millennium/ (pp. 127-133). Budapest: Semmelweis Kiadó.

Szumska, I. (2006). Az elhízás gyakorisága és hatása az életminőségre /The prevalence of obesity and its impact on quality of life/. In M.,Kopp, M.E., Kovács (2006). A magyar népesség életminősége az ezredfordulón /The quality of life in the Hungarian population in the millennium/ (pp. 210-218). Budapest: Semmelweis Kiadó.

Túry, F. Czeglédy, E., Papp, I., Dukay-Szabó, S., Babusa, B., Güleç, H., Mezei, Á., Szabó, K., Varga, M., Szumska, I. (2013). A táplálkozási magatartás zavarainak felmérése reprezentatív haza minta alapján-különös tekintettel a háttértényezőkre /The eating behavior and its disturbances survey on a representative Hungarian population - especially the background factors/. In É. Susánszky, Z. Szántó (Eds.), Magyar lelkiállapot 2013 /Mental health in the Hungarian population 2013/. (pp. 147-160). Budapest: Semmelweis Kiadó.

Weyers, S, Peter, R., Jeppesen, H.J., Siegrist, J. (2006). Psychosocial work stress is associated with poor self-rated health in Danish nurses: a test of the effort-reward imbalance model. Nordic College of Caring Science, Scandinavian Journal of Caring Sciences, 20, 26-34.

van der Linde, R.M., Mavaddat, N., Luben, R., Brayne, C., Simmons, R.K. (2013). Self-rated health and cardiovascular disease incidence: results from a longitudinal population-based cohort in Norfolk, UK. PLoS One 8:e65290.10/1371/journal.pone.0065290 (doi); PONE-D-12-40521 (pii).letöltve:2014.09.30.

Wu, S., Wang, R., Zhao, Y., Ma, X., Wu, M., Yan, X., He, J. (2013). The relationship between self-rated health and objective health status: a population-based study. BMC Public Health 13:320.http://www.biomedcentral.com/14712458/13/320. letöltve: 2014.09.30. 
AUTHOR'S ADDRESS:

Katalin Nagyváradi

University of West Hungary,

Sport Institute, Szombathely

Károlyi G. sqr. 4.

9700-Szombathely, Hungary

E-mail: itaky@mnsk.nyme.hu 